\title{
Diversitas Semut Arboreal (Hymenoptera: Formicidae) dan Potensinya sebagai Pengendali Ulat api (Lepidoptera: Limacodidae) Pada Tanaman Kelapa Sawit.
}

\begin{abstract}
ABSTRAK
Semut merupakan salah satu model yang ideal untuk mengukur dan memonitor keanekaragaman hayati. Permasalahan yang dilihat adalah bagaimanakah diversitas semut arboreal dan serangga hama pada tanaman kelapa sawit di Sumatera Selatan. Diduga semut arboreal (O. smaragdina) berpotensi sebagai pengendali hama ulat api pada tanaman kelapa sawit. Tujuan dari penelitian ini adalah (1) mempelajari diversitas semut arboreal pada berbagai umur tanaman kelapa sawit, (2) mempelajari diversitas serangga hama pada berbagai umur tanaman kelapa sawit, (3) Smengetahui potensi koloni dan bentuk sarang semut arboreal pada tanaman kelapa sawit, (4) menguji kemampuan memangsa semut $O$. smaragdina terhadap ulat api pada tanaman kelapa sawit dan (5) Menganalisis hubungan antara faktor abiotik dengan kehadiran semut rangrang dan serangga hama pada tanaman kelapa sawit. Penelitian ini telah dilaksanakan dari bulan Maret 2012 sampai dengan Februari 2013, pada Perkebunan kelapa sawit di Desa Tanjung api-api, Kabupaten Banyuasin Propinsi Sumatera Selatan. Hasil penelitian didapatkan diversitas semut arboreal (Hymenoptera: Formicidae) pada tanaman kelapa sawit terdiri dari 14 jenis semut yang termasuk dalam 5 subfamili dengan total individu 19516 ekor. Indeks diversitas jenis dengan kriteria sedang. Indeks ekuitabilitas memiliki kesamaan jenis. Indeks dominansi semut dengan kriteria rendah dan secara umum di dominansi oleh semut $O$. smaragdina dengan indeks nilai penting $(68,11)$. Indeks kesamaan kelimpahan jenis (BC) dipeoleh antara tanaman sawit umur dua dan empat tahun relatif sama yaitu $87 \%$. Diversitas hama ulat pada tanaman sawit didapatkan 5 jenis yaitu Setora nitens, Sethosea asigna, Thosea sinensis, Metisa plana, Parasa lapida, dari 2 famili (Limacodidaae dan Psychidae) dengan jumlah 10.556 individu dari ketiga umur tanaman kelapa sawit. Indeks diversitas jenis serangga hama dengan kriteria sedang. Indeks dominansi serangga hama kriteria rendah Jenis hama yang dominan adalah $S$. nitens dengan indeks nilai penting terbesar $(54,337)$. Indeks kesamaan kelimpahan jenis hama (BC) antara umur tanaman sawit berumur tiga dan empat tahun relatif sama (92\%). Semut $O$. smaragdina memiliki potensi sebagai pengendali hama pada tanaman sawit dengan cara pembentukan koloni yaitu pada teknik tangle foot didapatkan 7 sarang baru dengan total anggota koloni 65.273. Pada teknik non tangle foot tidak terbentuk sarang baru dengan jumlah anggota koloni 27.936 individu. Bentukbentuk sarang bervariasi ada yang berbentuk persegi panjang, segitiga, oval dan heksagonal. Terdapat hubungan yang erat antara faktor abiotik (iklim) dengan kehadiran semut arboreal pada tanaman kelapa sawit $\left(\mathrm{R}^{2}=0,80\right)$ begitu juga pada serangga hama $\left(R^{2}=0,66\right)$. Faktor abiotik yang berpengaruh sangat nyata terhadap keberadaan semut dan serangga hama adalah curah hujan dan lamanya hari hujan. Semut arboreal (O. smaragdina) mampu memangsa ulat api $S$. nitens, (uji
\end{abstract}


kesamaan rata-rata $87,50 \%$ ) dengan teknik non choice dengan hasil berbeda sangat nyata. Pada uji kesamaan rata-rata teknik choice berbeda nyata $(83,33 \%)$.

Kata Kunci: diversitas semut arboreal, diversitas serangga hama, potensi dan peran semut Oecophylla smaragdina, pengendalian hayati ulat api.

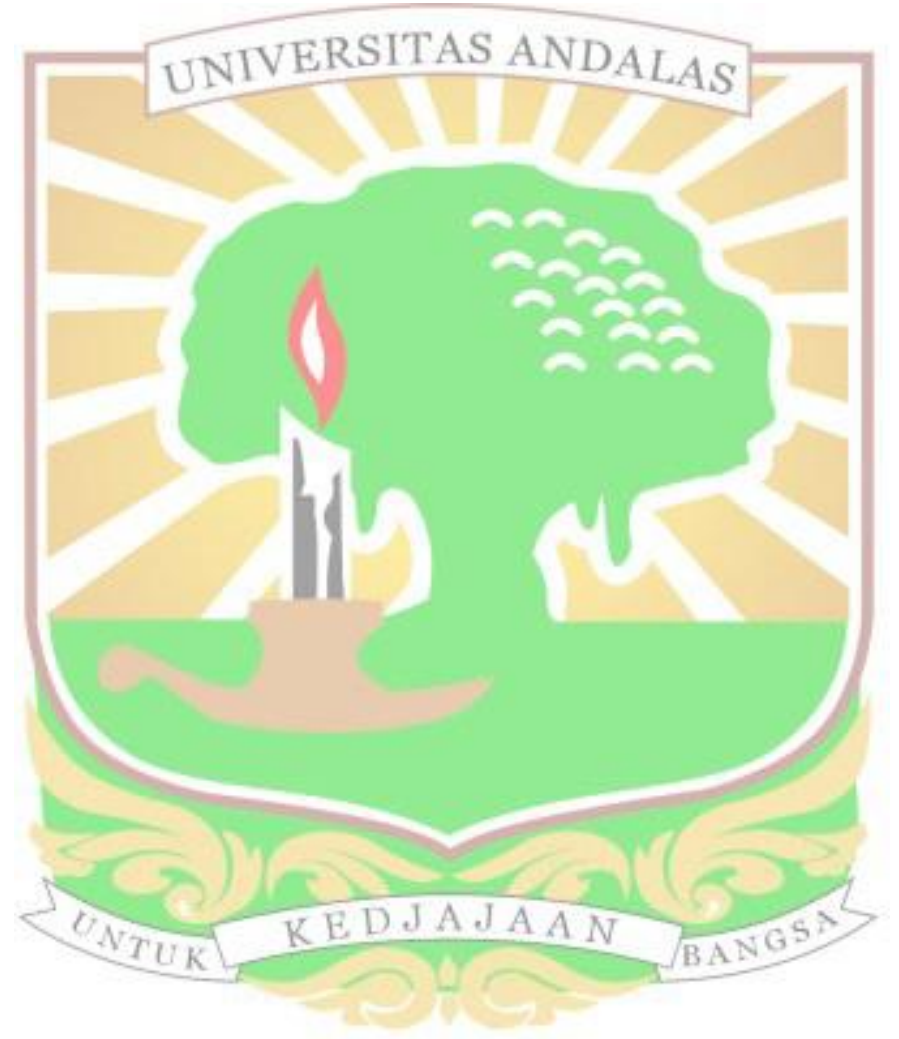

